\title{
Virtual cultural circle: promoting the health of nurses fighting the covid-19
}

\section{How to cite this article:}

Souza JB, Vendruscolo C, Maestri E, Bitencourt JVOV, Brum CN, Luzardo AR. Virtual cultural circle: promoting the health of nurses fighting the covid-19. Rev Gaúcha Enferm. 2021;42(spe):e20200158. doi: https://doi.org/10.1590/19831447.2021.20200158 a Universidade Federal da Fronteira Sul (UFFS), Curso de Graduação em Enfermagem. Chapecó, Santa Catarina, Brasil.

Universidade do Estado de Santa Catarina (UDESC) Chapecó, Santa Catarina, Brasil.

\section{ABSTRACT}

Objective: To report a virtual Cultural Circle experience implemented with nurses to allow them to dialogue and promote health amidst the pandemic of the Coronavirus Disease 2019 (COVID-19).

Method: Experience report of a virtual Cultural Circle based on Paulo Freire's framework. The stages were correlated to the oil lamp the symbol of the nursing profession: the lamp body was considered the Thematic Investigation, the lamp support corresponded to Encoding and Decoding, and the light corresponded to Critical Unveiling. Fourteen nurses working in different health settings located in different Brazilian regions participated.

Results: Two themes emerged: adjusting my inner light and taking care of my family and work.

Final considerations: The nurses exchanged experiences and strengthened themselves to overcome the challenges imposed by the fight against the COVID-19, acquiring autonomy to take care of themselves and provide care to others.

Keywords: Nursing. Coronavirus infections. Health promotion.

\section{RESUMO}

Objetivo: Relatar a experiência de um Círculo de Cultura virtual com enfermeiras, para viabilizar um espaço de diálogo e promoção da saúde, durante a vivência da pandemia da Coronavirus Disease 2019 (COVID-19).

Método: Relato de experiência de um Círculo de Cultura virtual, tendo como referencial o ltinerário Freireano. As etapas do Itinerário foram correlacionadas à lamparina, símbolo da enfermagem: o corpo da lamparina foi considerado a Investigação Temática; 0 suporte a Codificação e Descodificação; a luz o Desvelamento Crítico. Participaram 14 enfermeiras, atuantes em serviços de saúde de diferentes localidades do Brasil.

Resultados: Surgiram dois temas geradores para discussão: ajustando o meu interior; cuidando da família e do trabalho. Considerações finais: As enfermeiras compartilharam experiências e fortaleceram-se para superar os desafios no enfrentamento da COVID-19, desenvolvendo autonomia para cuidar de si e assistir os que necessitam dos seus cuidados.

Palavras-chave: Enfermagem. Infecções por coronavírus. Promoção da saúde.

\section{RESUMEN}

Objetivo: Reportar la experiencia de un Círculo de Cultura virtual con enfermeras, para habilitar un espacio de diálogo y promoción de la salud, durante la experiencia de la pandemia de la Enfermedad del Coronavirus 2019 (COVID-19).

Método: Relato de experiencia de un Círculo Cultural virtual, tomando como referencia el Itinerario Freireano. Las etapas del Itinerario se correlacionaron con la lámpara, símbolo de la enfermería: el cuerpo de la lámpara se consideró la Investigación Temática; soporte para codificación y decodificación; la luz de la Revelación Crítica. Participaron 14 enfermeras que trabajan en servicios de salud de diferentes lugares de Brasil.

Resultados: Surgieron dos temas generadores de discusión: ajustar mi interior; cuidando de la familia y el trabajo.

Consideraciones finales: Las enfermeras compartieron experiencias y se fortalecieron para superar los desafíos de enfrentar el COVID-19, desarrollando autonomía para cuidarse y asistir a quienes necesitan su cuidado.

Palabras clave: Enfermería. Infecciones por coronavirus. Promoción de la salud. 


\section{INTRODUCTION}

At the end of 2019, the Severe Acute Respiratory Syndrome Coronavirus 2, which causes the Coronavirus Disease 2019 (COVID-19), was identified in Wuhan, China, and spread worldwide. Pandemic was declared(1) in March 2020.

Health workers, mainly nurses, are on the front lines in the fight against the COVID-19, working in different health settings, from welcoming patients to delivering intensive care $^{(2)}$. This new context of physical and emotional exposure during practice emerges amidst the international campaign Nursing Now, intended to empower nurses as healthcare delivery protagonists.

Recognizing risks and planning interventions designed to decrease harm to the psychological health of the workers involved in the delivery of care to individuals diagnosed or suspected of having COVID-19 need to be a priority. Moral distress may hinder decision-making due to inner pressure (e.g., fear, inability to cope with suffering, lack of knowledge) or external pressure (e.g., hierarchical, communication, or organizational issues), leading to insecurity and uncertainty in the face of the pandemic, often, resulting in emotional breakdown ${ }^{(3)}$.

In this scenario, an opportunity to meet virtually with nurses and dialogue about the challenges imposed by the COVID-19 emerged, which enabled overcoming geographical barriers to exchange experiences, promote mutual learning, and relief fear and anxiety amidst the pandemic. This paper's objective is to report the experience of a virtual Cultural Circle implemented with nurses to provide them an opportunity to dialogue and promote health while fighting the COVID-19 pandemic.

\section{$\square$ METHOD}

This experience report originated from an extensionist action, guided by Paulo Freire's framework, which integrates three interconnected stages: (1) Thematic Investigation: intended to identify the participants' vocabulary universe, words and daily themes, originating generating themes; (2) Encoding and Decoding: intended to investigate the meanings of themes to expand knowledge and awareness of those involved; (3) Critical Unveiling: presentation of what was proposed in the objective encoding, interpreting the context and potential interventions ${ }^{(4)}$. Therefore, Cultural Circles are opportunities to learn and exchange different types of knowledge, in which the mediator and participants discuss the context and identify potential interventions together ${ }^{(4-5)}$.

Nurses working on the front line in the fight against the disease in Brazil took part in this study on April 30th, 2020.
Due to the need to impose social restrictions and the fact that each participant lived in a different location, the Circle was implemented virtually. An application free of cost was adopted, and the cameras of electronic devices, such as mobiles and computers, were used.

Eight nurses belonging to one of the authors' social circle were invited to participate in the activity. These nurses, in turn, invited other nurses to take part in the virtual Cultural Circle, totaling 14 nurses. Three days before the activity, the nurses received clarification via Whatsapp, on how to use the application, and date and time of the meeting. They were also asked to have an A4 paper sheet, markers, a candle and matches. The Circle lasted two and a half hours, and was mediated by a nurse with a Doctoral degree and experience in this type of approach. The activity's starting point was an analogy with the oil lamp, a symbol that represents the nursing profession. Incidentally, the bicentenary of Florence Nightingale, the precursor of the nursing profession, is celebrated in $2020^{(6)}$. Florence Nightingale is known as the "lady with the lamp" for using it when staying up late tending to the war wounded. A guitar and music were used as complements.

The virtual Cultural Circle brought the playful and scientific together to promote a reflection and the well-being of the participating nurses working on the front line in the fight against the COVID-19 pandemic. From this perspective, the framework provided by Freire was used with creativity and from a concrete action, covering its three interconnected stages, which as the lamp, needs its entire structure to provide light. This analogy, portrayed in Figure 1, enabled the implementation of all the three phases in a single meeting.

The Thematic Investigation was developed with the effective participation of all the nurses. The mediator presented an oil lamp and recalled Nightingale's achievements in the past, emphasizing that the lamp body needs to be adequately regulated to illuminate an environment. The following question prompted a dialogue: how are you adjusting yourself to the COVID-19 confrontation? Two themes were elected to shed light on the reflections within the Circle: adjusting my inner light and taking care of my family and work.

In the Encoding and Decoding phase, the mediator pointed out that the lamp support directs it, shedding light on the places where one wants to illuminate. Hence, the following question was asked: how do we adjust our inner light (promote health) and that of our families and work while fighting the COVID-19? On one of the A4 paper sheet's side, the participants described the possibilities to promote health and self-care. On the sheet's other side, they described how to take care of others (family and work) while the mediator sang Trem Bala [Bullet Train] by Ana Vilela, which elicited 


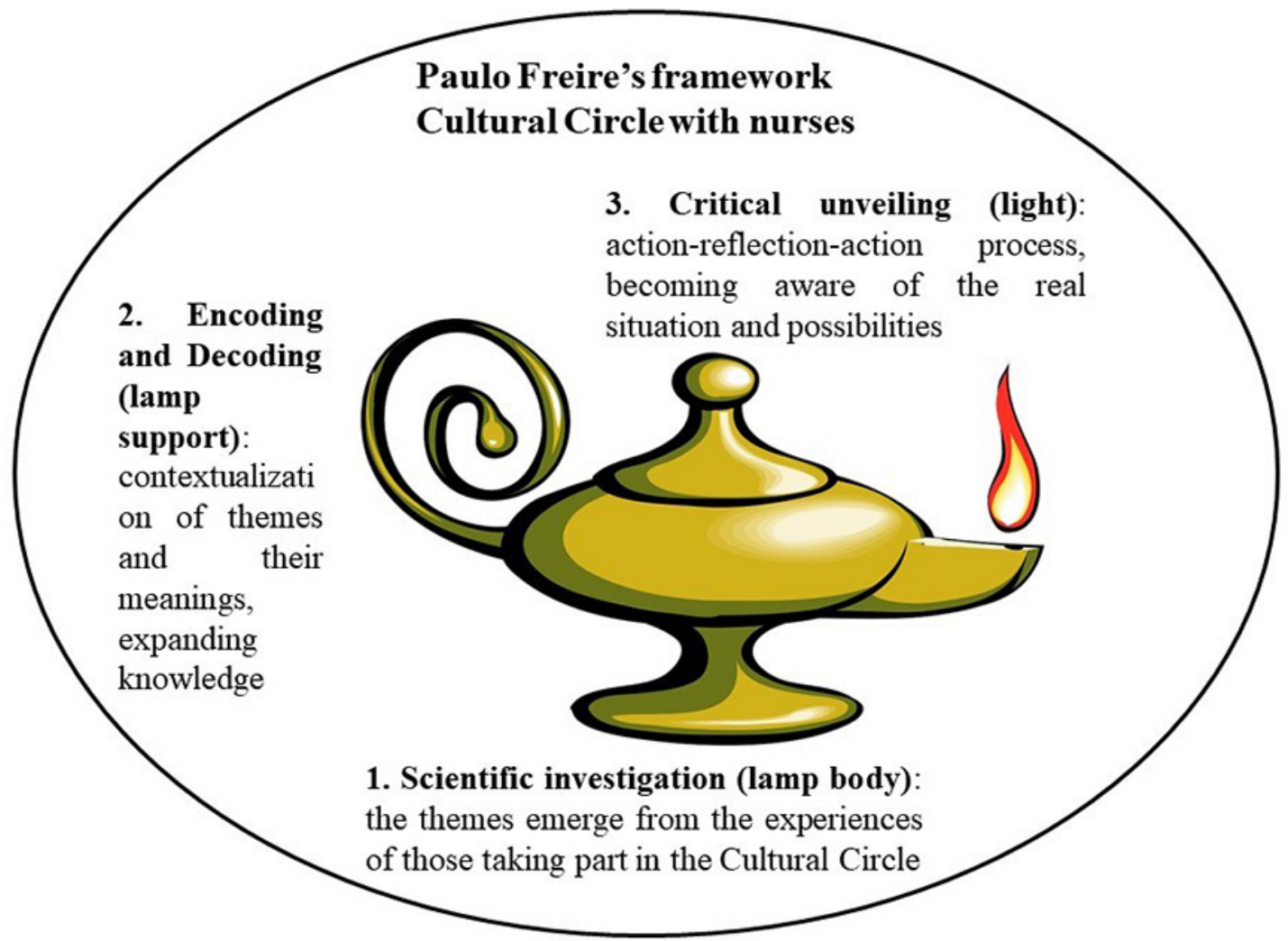

Figure 1 - Paulo Freire's framework: Analogy with the oil lamp Source: Adapted by authors based on http://thiesen.com.br/author/rafael/page/2/.

feelings and emotions. The themes were discussed in-depth, and each nurse critically and reflexively shared how they dealt with these situations, creating an environment illuminated by the exchange of knowledge.

Dialogical praxis facilitated acquiring awareness of which of the nurses' experiences were collective and which were private, leading to Critical Unveiling. The mediator lighted the oil lamp and pointed out its job of generating light. She invited each nurse to light her candle to the sound of the song Clarear [Lightening] by the Roupa Nova group. This symbolically led the nurses to reflect upon how not to put the flame of life out (alluding to the song lyrics) and promote our own health in times of the COVID-19?

Therefore, they unveiled their feelings and reflected upon possibilities that would enable them to cope with challenges and illuminate the repercussions of the COVID-19 in their lives, taking care of themselves and others. At this point, they also shared the meanings of having participated in the Cultural Circle.

In the end, they sang together Meu Abrigo, by Gabriela and Rodrigo Melim. The mediator noted that the Circle was meant to offer shelter (alluding to the song's lyrics, which symbolizes care) to the nurses, who have provided shelter (care) to so many who need to be cared for in the fight against the COVID-19.

\section{RESULTS AND DISCUSSION}

The participant nurses were women aged between 40 and 51 years old, with more than 18 years of experience, currently fighting the COVID-19 in different settings: Hospital Care, Primary Health Care, or in the Management of Municipal and Regional Health Departments. They all lived in Brazilian states: Santa Catarina, Rio Grande do Sul, Paraná, São Paulo, Rio de Janeiro, and Bahia.

The generating themes were widely discussed: adjusting my inner light and taking care of my family and work. Resignification was reached in the Encoding and Decoding phase with a fervent dialogue, strengthening the group in which the participants identified with each other through the exchange of experiences, which is briefly presented in Figure 2. 


\section{Adjusting my inner light}

\section{Keeping myself busy}

Doing things I like Being more grateful, complaining less Having faith that better days will come

Getting closer to God Appreciating life's little things Reading more books, less news Keeping hope alight Learning with experiences Taking care of myself Alleviating fear and stress Unloading anxiety Listening to good music Living life

\section{Taking care of my family and work}

Enjoying my family

Taking care of loved ones

How to adjust my inner light, that of my family and work while fighting the COVID-19?

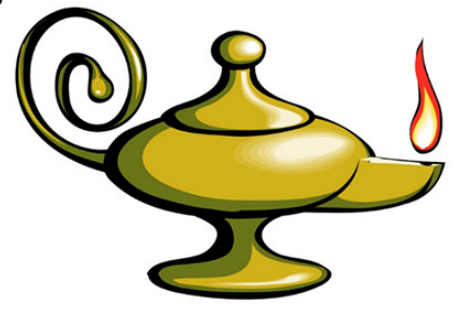

Taking care only of what is necessary around the house

Avoiding stressing husband and children

Reassuring my family

Helping the kids with school work

Supporting the elderly in the family

Seeking reliable information

Keeping doing good work

Working with joy, not fear

Not bringing problems home

Being a competent nurse

Supporting co-workers Wearing PPE properly

Figure 2 - Adjusting my inner light, that of my family and work: possibilities to promote health Source: Adapted by authors based on hitp://thiesen.com.br/author/rafael/page/2/.

In the Critical unveiling phase, the nurses expressed their perceptions regarding their inner light and their external environment amidst the fight against the COVID-19, in the process of action-reflection regarding the two generating themes, which culminated in a critical awareness regarding limitations and potential(5) to continue to live without putting out the flame of life. This movement was intended to promote the nurses' health and of those around while facing the pandemic's consequences.

The Política Nacional de Promoção da Saúde(7) [Brazilian Health Promotion Policy] is attentive to the concept of health as a result of a series of determinants, taking people's happiness into account. Health promotion is expressed through a set of values such as equity, social justice, ethics, and autonomy, among others, so that there is a need to fight for conditions and resources that are essential to its implementation ${ }^{(7)}$.

In agreement with Freire's assumptions, mobilizing individuals in this direction using a dialogical praxis approximates and promotes affective relationships, humbleness, and respect toward each other, others, and the world. Freire proposes his pedagogical method to be implemented through Cultural Circles, emphasizing the protagonism of those involved, their autonomy, and emancipation, leading people to become aware of problems and unveiling potentialities by reflecting together with their peers the situations they experience. Hence, it promotes critical perceptions and, consequently, empowers people $\mathrm{e}^{(4-5)}$. During the Cultural Circle, the nurses took care of each other and were cared for, enhancing empowerment and motivation to promote health and provide care, which is the essence of Nursing.

From this perspective, the participants were encouraged to reflect upon their experiences and implications to themselves (adjusting their inner light) and others (taking care of their families and work). Hence, they felt welcome by the Circle during a time when they needed shelter and an opportunity to exchange ideas. This experience promoted health and empowered them, as shown in Figure 3, with shared meanings.

An increase in anxiety and stress is observed in pandemic times among health workers directly dealing with the disease's fight. Coupled with these feelings, the COVID-19 has changed the way people live, work, and organize, leading to feelings of helplessness and abandonment, increasing uncertainty regarding the future ${ }^{(8)}$. The nurses working on the front lines in the fight against the COVID-19 face stressors such as greater exposure to the infection, fear of infecting others, excess workload, and face fatal cases, which cause frustration for not being able to avoid deaths ${ }^{(9)}$. Therefore, continuous health promotion initiatives should be immediately implemented while preparing workers to adapt to the post-pandemic ${ }^{(9)}$. 
We are the "Florences" of today What would Florence do right now?

I also want to make a difference May I shine light wherever I go I feel transformed and enlightened I'm enlightened I felt cared for Thanks for welcoming me I needed this opportunity

We need more moments like this I want to take care of myself to illuminate other lives

COVID-19 will not take my shine away You brighten my day

I feel relieved of my anxiety and fears It was good to have shelter, so now I can be a shelter for others

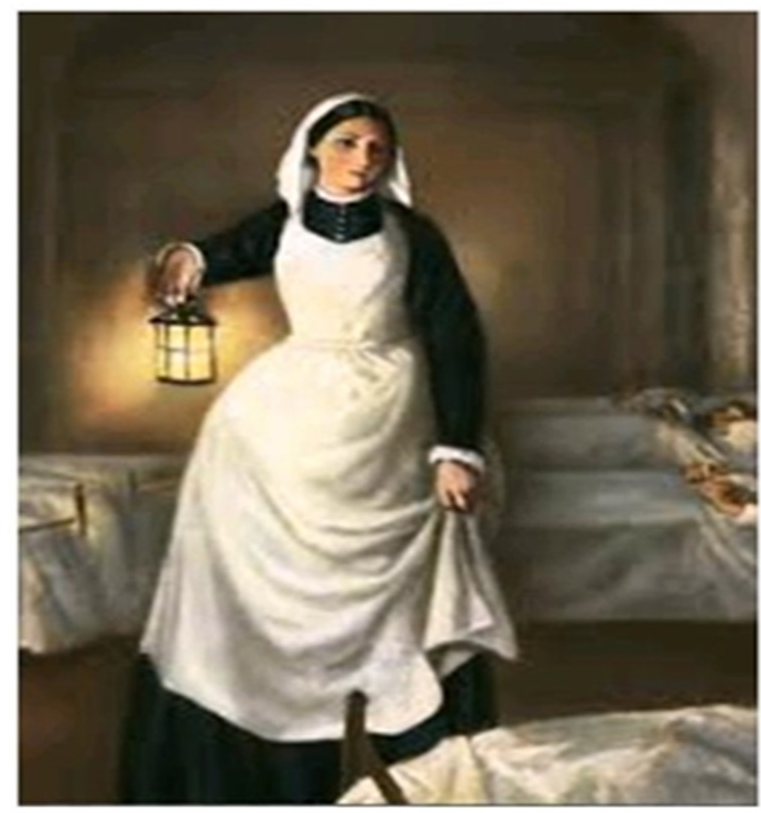

Figure 3 - The nurses' meanings regarding their experiences in the virtual Cultural Circle Source: Adapted by the authors based on https://www.spiritfanfiction.com/jornais/grades-mulheres--florence-nightingale-1820-1910-8531052

The virtual Cultural Circle became an opportunity to promote health, a time permeated by the exchange of knowledge, respect, and ethics among all those involved. The participants could express their feelings, mirroring in the past, on Florence Nightingale's history, projecting the future, and adjusting their inner light and external environment in a mutual learning process to reach well-being despite the pandemic.

Nightingale used statistical information to establish her team's behavior during the Crimean War in 1854, influencing political-governmental action and persuading the authorities to decrease mortality based on hygiene measures ${ }^{(10)}$. Her legacy influenced nurses' practice and encouraged them to assume a technical-scientific and political protagonism, using practices committed with social well-being, within care dimensions, management, and education, in accordance with Freire's assumptions(5), as well as health promotion and empowerment ${ }^{(5,7)}$

\section{FINAL CONSIDERATIONS}

The virtual Cultural Circle provided an opportunity to dialogue and promote health amidst the COVID-19 pandemic. It proved to be a possibility to establish fruitful relationships among nurses, leading to collective reflection by exchanging experiences and creativity, awakening for critical awareness.
In the bicentenary of the precursor of nursing, nurses have stood out as essential professionals in the fight against the COVID-19, a fact evidenced by their perceptions expressed during the experience, showing this study's contribution to the nursing practice in all its dimensions.

Despite the limitations of social distancing, the virtual environment enabled social interaction, historical rescue, and the future projection of the profession. It was an opportunity to promote nurses' health, emerging as a technological innovation that can be adopted in research, management, and nursing care.

\section{REFERENCES}

1. Carico RR, Sheppard J, Thomas (B. Community pharmacists and communication in the time of COVID-19: applying the health belief model. Res Soc Adm Pharm. 2020. In Press, Corrected Proof. doi: https://doi.org/10.1016/j.sapharm.2020.03.017

2. Bortoli CSH, Garcia LNJC. Nursing perspectives and the "Nursing Now" campaign [editorial]. Rev Bras Enferm. 2018;71(5):2351-2. doi: https://doi. org/10.1590/0034-7167.2018710501

3. Ornell F, Halpern SC, Kessler FHP, Narvaez JCM. The impact of the COVID-19 pandemic on the mental health of healthcare professionals. Cad Saude Publica 2020;36(4):e00063520. doi: https://doi.org/10.1590/0102-311×00063520

4. Heidemann ITSB, Dalmolin IS, Rumor PCF, Cypriano CC, Costa MFB, Neves A, Durand MK. Reflections on Paulo Freire's research itinerary: contributions to health. Texto Contexto Enferm 2017;26(4):e0680017. doi: https://doi. org/10.1590/0104-07072017000680017 
5. Freire P. Pedagogia do oprimido. 64ª ed. Rio de Janeiro: Paz e Terra; 2017.

6. Petry S, Teixeira Filho CA, Mazera M, Schneider DG, Martini JG. Autonomia da enfermagem e sua trajetória na construção de uma profissão. Hist Enferm: Rev eletrôn. 2019 [cited 2020 May 4];10(1):66-75. Available from: http://here. abennacional.org.br/here/v10/n1/a7.pdf

7. Ministério da Saúde (BR). Portaria nº 2.446, de 11 de novembro de 2014. Redefine a Política Nacional de Promoção da Saúde (PNPS). Diário Oficial da União. 2014 nov 13 [cited 2020 May 4];151(220 Seção 1):68-70. Available from: https://pesquisa.in.gov.br/imprensa/jsp/visualiza/index. jsp?data $=13 / 11 / 2014 \&$ jornal=1\&pagina=68\&totalArquivos=212

\section{- Corresponding author:}

Adriana Remião Luzardo

Email: adriana.luzardo@uffs.edu.br

\section{- Authors' contributions:}

Conceptualization: Jeane Barros de Souza Silva.

Data curation: Jeane Barros de Souza Silva, Carine Vendrusculo.

Formal analysis: Jeane Barros de Souza Silva, Carine Vendrusculo, Eleine Maestri, Júlia Valéria de Oliveira Vargas Bitencourt.

Investigation: Jeane Barros de Souza Silva, Carine Vendrusculo.

Methodology: Jeane Barros de Souza Silva.

Visualization: Jeane Barros de Souza Silva, Carine Vendrusculo, Eleine Maestri, Júlia Valéria de Oliveira Vargas Bitencourt, Crhis Netto de Brum, Adriana Remião Luzardo.

Writing - original draft: Jeane Barros de Souza Silva, Carine Vendrusculo, Eleine Maestri, Júlia Valéria de Oliveira Vargas Bitencourt.

Writing - review and editing: Jeane Barros de Souza Silva, Carine Vendrusculo, Eleine Maestri, Júlia Valéria de Oliveira Vargas Bitencourt, Crhis Netto de Brum, Adriana Remião Luzardo.
8. Gallasch CH, Cunha ML, Pereira LAS, Silva-Junior JS. Prevention related to the occupational exposure of health professionals workers in the COVID-19 scenario. Rev Enferm UERJ. 2020;28:e49596. doi: https://doi.org/10.12957/reuerj.2020.49596

9. Schmidt B, Crepaldi MA, Bolze DAS, Neiva-Silva L, Demenech LM. Saúde mental e intervenções psicológicas diante da pandemia do novo coronavírus (COVID-19). Estud Psicol. 2020;37:e200063. doi: https://doi. org/10.1590/1982-0275202037e200063

10. Martins DF, Benito LAO. Florence Nightingale e as suas contribuições para 0 controle das infecções hospitalares. Universitas: Ciênc Saúde. 2016;14(2):15366. doi: https://doi.org/10.5102/ucs.v14i2.3810

\section{Associate editor:}

Dagmar Elaine Kaiser

Editor-in-chief:

Approved: 09.25.2020
Maria da Graça Oliveira Crossetti 